\title{
Paul Christophersen: a largeness of vision
}

\section{DAVID CHRISTOPHERSEN writes}

about the remarkable life of his father, whose death on 30th December 1999 at 88, peacefully at home in Cambridge, England, brought to an end one of the last living links to the tradition of analytical grammar and philosophy associated with the great Danish Anglicist Otto Jespersen.

Already as an undergraduate at Copenhagen University in Denmark, Paul Christophersen's correspondence with Otto Jespersen and comments on his ideas led to collaboration with Jespersen on his monumental and multivolume Modern English Grammar and to early international recognition by 1939 with the publication by Oxford University Press and Munksgaard of his Copenhagen doctoral thesis on the development and use of the article in English.

This was, however, only the beginning of a career that was to concern itself increasingly with the sociolinguistic and psychological implications of bilingualism and biculturalism - he drew from his own vivid and occasionally painful experiences of this - as well as related questions of language planning and teaching and the very subsidiary role, as he saw it, that applied linguistics should play in these matters.

His origins were socially humble: a family of small-holders from the island of Zealand. His gifted father's formal education ended after a few years at a village school, supplemented later by evening classes. His mother had no formal education. At twelve his father died leaving his mother, four siblings (one crippled by polio) and himself facing an uncertain future. Consequently he began part-time work as a messenger and delivery boy. A photo just before his father's death shows Paul with an intricately carpented model sailing ship, about three feet long, a bark made by himself, complete with sails and rigging, capable of navigating Copenhagen's city ponds, and which still stands in his library in Cambridge. A year later he was planning a comparative grammar of the classical and modern languages he was learning in school, noting - this before the days of radio - that his English teacher had acquired a cockney accent and beginning his study of artificial languages such as Ido and Novial - successors to Esperanto. His notebooks from this period show his solutions to chess problems in Ido and record his reading of imaginative literature (translations of Andersen) in that language. A timetable pencilled in the back of an Old Norse reader studied in his Danish classes records the education the Danish state was providing free of charge: two classical and three modern languages, science subjects and maths.

\section{Christophersen in English Today}

Christophersen, Paul. ET8, Oct 86. 'A history of the plupluperfect'

-ET11, Jul 87. 'In defence of RP' - Received Pronunciation defended as the standard accent for British and European English

- ET15, Jul 88. "'Native speakers" and world English' - What is a 'native language' and what is a 'native speaker' of English? Do the terms need to be revised?

- ET17, Jan 89. 'The cohorts are coming' new meanings for cohort

- ET19, Jul 89. 'The prescriptive bugbear' comments on Fairman in ET17

-ET23, Jul 90. 'The Germanic legacy' - an assessment of what English has inherited from Anglo-Saxon, Low German and the Scandinavian languages

- ET27, Jul 91. 'A bilingual Denmark' - the state of Denmark and other small countries when every citizen speaks English as well as the national language

- ET31, Jul 92. "Native" models and foreign learners' - a consideration of 'nativeness', 'foreignness', expertise and language allegiance

-ET33, Jan 93. "Two sound changes in England' - a review of Anthea E. Sullivan, Sound Change in Progress (University of Exeter Press, 1992) 
In 1939, he received a scholarship to study in Cambridge and, following the Nazi invasion of Denmark, he found himself stranded in a small college (Corpus) where courtesy, gentleness and refinement of spirit won his gratitude and effected an emotional maturing in him expressed entirely in English and in terms of English values. Looking back at his published work from the thirties, he felt its English style was a 'suit that didn't quite fit', though it seems elegant to the casual observer and attracted attention for decades. (A Japanese translation of 'The Articles' appeared in 1958.) On his own admission a large part of his identity and loyalty had become English.

The seeds had been planted for his reflections on bilingualism expressed later in his Penguin book of 1973, Second Language Learning and elsewhere: Bilingualism can imply not only possessing two cultures and identities, but also sometimes, according to circumstances, greater psychological and linguistic maturity in the second-learnt language

Emotive concepts such as 'native speaker' and 'mother tongue', belonging to an era of romantic nationalism, tended in his view to falsify the reality of language learning and personal development, as identity is not fixed at birth and the individual has a choice. For years he was to document the countless individuals whose second language and identity was the dominant one, often for creative purposes, from the Roman poet Ennius (with whose statement that he had 'three hearts', one for each of his languages, Greek, Oscan and Latin, he deeply sympathized) to the German romantic poet Chamisso, who began life as a French aristocrat.

A language community, therefore, being a freely entered cultural community, not a group of passport-holders or people with a specific genetic inheritance, has no nationalistic claim of ownership to a language, but rather a custodial responsibility (especially in the case of a world language like English), for its stability and precision. The latter point he was to develop forcefully in recent years, being critical of the confusion that led some linguists and lay-people to assume that because a linguistic scientist's role is quite properly the description of linguistic phenomena, policy-makers should not prescribe policies affecting language.

After completing a Cambridge doctorate on medieval balladry and a strenuous two years at the BBC, broadcasting to occupied Denmark in Danish, he became a research assistant at The Royal Institute of International Affairs, where special permission had to be granted for a Dane to have access to Foreign Office materials. A close friend, T. E. Utley, who was privy to the discussions that led to this permission, was tickled by the unusual logic of the clinching argument: the assurance that 'one could not hear that Paul Christophersen was not English'.

After the war he was sceptical about too cloistered an academic life and had an idealistic desire to be a bridge-builder in the new world order. He participated in UNESCO's founding conference and preparatory commission, as part of the Danish delegation and later as Danish representative. In 1946, hoping to be of service to two nations, he reluctantly accepted the chair of English at Copenhagen University, his heart and identity really being in England. Fully intending to become a British citizen after the war, this crown appointment now made a change of citizenship inappropriate and impossible. His oldest Danish friend having been executed by the Germans during the war, stifled by the currency and travel restrictions of post-war Europe, lonely and feeling he needed more pioneering work, he resigned, amidst public consternation, in 1948 and accepted the chair in English at Ibadan University in colonial Nigeria.

He arrived in a converted bomber at Kano airport and saw on the airport building 'a line of scraggy-necked vultures' and years later he was still to recall the excitement and anticipation he felt. Ibadan had gifted and motivated undergraduates, including the future novelist Chinua Achebe - 'the best were the equal of any Europeans' he noted - and this period saw the beginning of his fifty-year marriage to his English wife Peggy, the appearance of his study of medieval Anglo-Scandinavian ballad relations The Ballad of Sir Aldingar (OUP, 1953) and, after his departure from Africa, of $A n$ English Phonetics Course (Longman, 1958), material he had used with Africans but which found a wider market than expected. An Indian edition is to appear later this year.

A deeply emotional man, whose reaction to a poem or piece of music could be gauged by his trembling lip and eyes filling with tears, his gentleness was tested on returning to Scandinavia and a chair at Oslo, where British attitudes, he 
discovered, seemed at times to be disturbingly condescending to her continental well-wishers and certainly not, he felt, in Britain's best interests, culturally or politically. The colonial attitude of one or two British representatives in Norway called into question his own publicspirited ideal of being a bridge-builder between Britain and Scandinavia, but undoubtedly added refinement and sharpness to his thoughts on bilingualism and cultural identity. His son well remembers consulting his father at this time about an essay for his Norwegian school about the vikings; from his lucid but melancholy explanation of the Scandinavian invasions of England it was clear who his father's hero was: King Alfred, the man of action and refined learning. But, this admiration for English gentleness was tinged with sadness.

However, despite his difficulties he had warm feelings for Norway and appreciated his Norwegian colleagues, one of whom, A. O. Sandved, collaborated with him on their jointly published Advanced English Grammar (Macmillan, 1969). Oslo's Aftenposten newspaper has recalled the creative energy he brought to English studies at Oslo and more widely in Norway: 'His spirit hovered over the waters and still does to some extent.'

The Oslo appointment was punctuated by a visiting professorship at Atlanta's Emory University and followed in 1969 by eight years at the University of Ulster, where Northern Irish hospitality made up for many past frustrations. In his inaugural lecture on receiving a personal chair at Ulster he managed to sum up some of his aims. He entitled the lecture "Settling Hoti's Business", a reference to Browning's poem about a scholar whose life's work was the elucidation of the accentuation of two classical Greek words, $\mathrm{Ho}$ and $\mathrm{Ti}$.

'I want to add only one final thought,' he says, 'Browning's grammarian, after a lifetime of patient toil, after settling Hoti's business and other linguistic problems, was buried appropriately on a high mountain where "stars come and go". He was concerned in his life with little things, almost trivial things, but saw them largely.'

Widely read in five languages, Paul Christophersen had a largeness of vision that continued until his death. On retirement, he went to the Arab world to teach, began the study of Arabic, published a translation of a Danish classic, as well as a stream of learned articles on subjects as diverse as 'International Contacts in Carolingian Europe', 'The Germanic Heritage', 'Jespersen and Second-Language Learning', and 'Native Speakers and World English' covering areas of study too numerous to list in the present memoir. A selection of these papers was published in book form shortly before his death, entitled $A$ Linguist's Credo (Rask, 1999).

As meticulously courteous as he was logical, he suffered in a world where not all were as honourable in those respects as he was. He regarded himself as a failure, feeling his radical questioning of common assumptions held by linguists as well as lay-people had fallen largely on deaf ears.

A Linguist's Credo, a collection of Paul Christophersen's more recent papers, was published in 1999 by Odense University Press, as RASK Supplement Vol. 9. DDK 200.00. ISBN 87-7838-405-2. <press@forlag.ou.dk>

\section{A Danish English gentleman of the old school}

Knowing Paul Christophersen and being able to regard him as a good professional friend was a privilege that emerged from editing English Today and living in Cambridge. I am glad indeed to have been instrumental in making possible his nine contributions to ET, as listed in the box on p. 3. Talking with him was always absorbing, but at times darkened by his abiding sense of betrayal by a British cultural establishment that failed to appreciate his commitment to British ideals. His achievement and his unique combination of professorships in EFL (Denmark), ESL (Nigeria) and ENL (Northern Ireland) universities were entirely remarkable in an age of turmoil and transformation. He won more victories than he knew.

Tom McArthur 